\title{
PRESERVING INDIGENOUS KNOWLEDGE THROUGH FOLK NARRATIVES: PODI AND NGOYU
}

\author{
Yvonne Michelle Campbell, Kamila Ghazali \& \\ Sakina Sahuri Suffian Sahuri \\ Department of English Language \\ Faculty of Language and Linguistics \\ University Malaya \\ (willonne2003@gmail.com )
}

\begin{abstract}
This paper explores the Indigenous Knowledge (IK) within Bidayuh folk narratives or dondan. It also discusses the importance of folk narratives, an intangible cultural heritage, with reference to the Bidayuh Bau-Jagoi community. Studies have looked into the preservation of tangible and intangible cultural heritage through the process of documenting and introducing them to younger generations through the state education system. However, documentation itself is not enough. Research needs to be done to discover and understand the IK embedded within these cultural heritages, particularly the intangible aspects. Cultural Linguistics (Sharifian, 2011) is the framework chosen for analysis. The findings of this study discuss two important types of IK which are significant to the Bidayuh Bau-Jagoi community, namely podi (paddy) planting and headhunting. These two types of IK are analysed within the context of the Gawai which is the cultural celebrations of the Bidayuh community
\end{abstract}

Keywords: Indigenous Knowledge, Bidayuh, folk narrative, Gawai, podi, headhunting

\section{Introduction}

Indigenous knowledge (IK) is an important part of any community. IK is said to be unique to a particular culture or society because it is built and developed based on the experience and knowledge of a particular cultural group. IK consists of information that involves the lives and beliefs of an indigenous 
community and has been collected and passed on through many generations. It contains the codes and guidelines that members of the community live by and these in turn form the community's cognitive structure. Thus, IK could be considered as a collection of knowledge gained through several generations and consists of guidelines on living (Chielotam, 2012; Harrison, 2007).

According to Warren (1991), IK is the basis for nearly all aspects of life including agriculture, food preparation, health care and education, to name a few, as well as the basis for communication and decision making. As IK is the reservoir of information, it also assists in the conservation and sustainability of societies (Flavier, de Jesus \& Navarro, 1995). In this regard, IK is an educational tool among indigenous communities. It is through IK that members of a community, especially the younger generations learn aspects of everyday life and how to handle and solve everyday problems.

IK may be transmitted in many forms, either through tangible cultural heritage such as artefacts, monuments, clothing, pottery, buildings, and works of art; or through intangible avenues such as chants, songs, rituals and narratives. Intangible cultural heritage is less obvious compared to tangible ones and relies mainly on language as the main vehicle to transmit and maintain them within the community. However, as largely contended (Harrison, 2007), IK is at risk of erosion and ultimately moribund as it is very fragile. This would be particularly so when it is translated from the original language to another as nuances only understood by indigenous speakers may be amiss.

Warren (1991), also argues that IK is the basic component of a nation's knowledge system since it consists of the people's skills, experiences and insights used to sustain and improve livelihood. In other words, IK could be regarded as the knowledge for survival.

In fact, a significant amount of global knowledge is derived from IK especially in the fields of agriculture, veterinary, medicine, and even engineering. This is because IK usually has a firm understanding of the environment and due to this, it is dynamic in nature, in that it is constantly changing and adapting to the changes and influences of the environment (Flavier et al., 1995).

Most studies have looked into the preservation of both tangible and intangible cultural heritage as well as documented and preserved these various forms of cultural heritages (Pugh-Kitingan, Hussin, \& Baptist, 2009, Hussin, 2008, 2007). However, preserving alone is not enough. There is a need to study these cultural heritages, especially the intangible ones in order to understand the embedded IK. Many IK systems are at risk of being extinct, 
because international knowledge systems are in favour of modern knowledge. There is, therefore a great risk of IK being lost and with it the loss of valuable information about sustainable living (Tamit, 2009). Besides that, studies and preservation of the Bidayuh cultural heritage are also very limited.

This paper is aimed at exploring the IK embedded within the Bidayuh BauJagoi folk narratives and how these folk narratives are regarded as a source of IK.

\section{Indigenous knowledge in Bidayuh folk narratives}

Being one of the many ethnic groups in Sarawak, the Bidayuh has a great number of oral traditions that has yet to be explored. The Bidayuh mainly resides in the Kuching and Serian Divisions in Sarawak, Malaysia and are believed to have originated from West Kalimantan (Chang, 2002, 2004). They are divided into four main groups based on their geographical locations: the Bukar-Sadong group in Serian District, the Bau-Jagoi group in Bau District, the Biatah group in Kuching District and the Salako-Lara group in Lundu District. The focus of this study is on the Bau-Jagoi group in Bau District.

Although the Bidayuh have a number of oral traditions in both narrative and non-narrative forms, this study focuses on the narrative forms of Bidayuh oral traditions, in particular, the dondan. The dondan are stories told by the community elders, consisting of both men and women to a variety of audience. Usually told in the evenings, as a form of entertainment in the olden days, dondan could either be told while members of the community are gathered at the longhouse gallery, also known as awah botang romin, where the audience is large and varied; or in the garden house, or bori umoh, to a mainly younger audience; or even in the ceremonial house, or Baruk, to teenage boys and men only (Ridu, Jitab, \& Noeb, 2001). There are different types of dondanfolktales, myths, legends and fables. Sengi, which are stories of origin and geneology, as well as girutu, children's stories, are also considered as dondan.

As there was no other form of entertainment, the dondan was told as a favourite pastime among the people. In fact, the dondan was also considered as a medium of education since there was no formal education in those days. It was through dondan that important knowledge and information was passed down to members of the community, especially to the younger generations.

This being the case, the dondan contains invaluable IK, which were important to the people especially in living their daily lives. The findings of this paper discuss two important IK, which are reflected in the dondan analysed as well as the two main sources of living for the Bidayuh Bau-Jagoi community. 


\section{Dondan as a source of IK}

The Bidayuh dondan tells stories that contain everyday characters and are set in settings, which the Bidayuh are familiar with such as the village (kupuo), longhouse (botang romin) and the forest (torun). The characters too are those, which the Bidayuh people can relate to. Even so, the characters may also be mystical beings, which the Bidayuh believed in, and are familiar with these. In fact, these mystical beings are believed to be a part of the Bidayuh community and have the ability to influence the lives of the people.

It is because the dondans tell stories about the everyday life of the people or are set in a Bidayuh setting, it is, therefore, common to find information regarding the Bidayuh way of life within these dondans and the information reflects closely how the Bidayuh lived their lives.

\section{Gawai}

Gawai is 'a combination of festivals, rituals and ceremonies throughout the farming year, centred around the production of podi' (Patrick, 2002:272). Gawai is usually a form of celebration conducted after the harvesting season, but in the olden days, Gawai was a form of celebration combined with rituals connected to seeking blessings from the spirits. Gawai was centred on the production of podi, or (rice) paddy, but it was also a form of celebration ritual related to another activity, which is headhunting or ngoyu. This Gawai is known as Gawai Mukah.

There are many different types of Gawai, which are related to the podi planting process. According to Patrick (2002), there are six Gawai related to podi:

Table 1 - Gawai related to Podi

\begin{tabular}{|l|l|l|}
\hline & TYPES OF GAWAI & PURPOSE \\
\hline 1. & Gawai Poris Oran & $\begin{array}{l}\text { Conducted before clearing the area } \\
\text { for farming }\end{array}$ \\
\hline 2. & Gawai Papau & $\begin{array}{l}\text { Conducted after clearing of the area } \\
\text { for farming }\end{array}$ \\
\hline 3. & Gawai Tugar & $\begin{array}{l}\text { To bless the cleared plots of land } \\
\text { before burning }\end{array}$ \\
\hline 4. & Gawai Ngirangan & To deter pests or evil spirits \\
\hline 5. & Gawai Ayuh Obuo Sowa & Held after the harvest \\
\hline 6. & Gawai Juran Tubi Bauh & To bless the new rice \\
\hline
\end{tabular}

Gawai Mukah, on the other hand, is a Gawai specifically for the skulls taken during headhunting. This was conducted in the olden days when 
headhunting was still the practice. The Gawai is meant to appease the spirit of the skull and ask for protection from the spirit.

This study discusses the cultural conceptualisations of podi (paddy) and ngoyu (headhunting) within the context of Gawai and how these IK are reflected in the dondan.

\section{Methodology}

This paper applies the Cultural Linguistics analytical framework as a tool to explore the IK of folk narratives by focusing on not only the content but the language as well. Cultural Linguistics analyses the relationship between language, culture, and conceptualisation. Conceptualisation here refers to the meaning and message that is affected by culture and reflected through language. There are three analytical tools used, namely Cultural Schema, Cultural Category and Cultural Metaphor.

Cultural Schema looks at the schemas, which are culturally related. The schema is defined as an abstract and universal mental interpretation of knowledge, which comprises an organised pattern of thoughts or behaviour that aids daily activities through learning and incorporation of new connotations (Kellog, 1995). Sharifian (2011) contends that Cultural Schema is a sub-class of the schema that is constructed culturally. Cultural Category analyses the division and classification of lexical items found in the dondan. Cultural Metaphor explores the figurative expressions which are related to culture.

For this particular study, 15 dondans were recorded, transcribed, and analysed. The excerpts analysed are literally translated into English. The translations are literal for the purpose of authenticity. Although they are not in grammatical forms, the interpretations are discussed within the texts. These dondans were recorded, using an MP4 recorder, from two elderly storytellers Rago anak Rapong, aged 83 and Daweg anak Raweh, aged 88, from Kampung Stass and Kampung Skibang in Bau, Sarawak. The time and place for the story telling sessions were set up after permission was granted from these storytellers. This was done mostly in the evening, after dinner as well as during weekends.

\section{Discussion}

\section{Cultural Schemas}

The analysis of the dondan revealed patterns of knowledge that assist the Bidayuh in living their daily lives. These Cultural Schemas guide the people 
on what they should do and how they should act or behave in different situations. Cultural Schemas also reveal matters that may be important for the Bidayuh. Some of the common Cultural Schemas found in the dondan are based on the following themes:

- Relationships

- Gawai and Paddy planting

- Hospitality

- $\quad$ Roles and responsibilities

- $\quad$ Hunting and headhunting

However, for the purpose of this paper, only podi planting and headhunting are the focus. Both are discussed in the context of Gawai, a form of traditional celebration according to the Bidayuh custom.

\section{Cultural Schemas of podi}

The analysis of the 15 dondans revealed that Cultural Schemas of podi featured significantly. This shows how podi plays an important role in the lives of the Bidayuh people. First is the significance of podi in the Bidayuh community. This could be found in one of the dondan, Dondan Tibulit:

Oni kowo' de man pak eh pe nyam paguh ngan to' man danih, doik nak de nyam to' man tanak datik, modud nyam otin nyek dak eh, ponai bijak nyam bobak nye dak eh. Pitar nyam nyek dak eh in neh.

(What is it that the people eat up there, so good it seemed, not like what we eat here on the ground? The heart is cool; the mouth is wise. One becomes wise because of it.)

(D8, L4-7)

In the above extract (D8, L4-7), the origin of podi is revealed indirectly. It was believed that podi originally came from the Skies (rongit) when it was stolen and brought down to Earth by a tibulit (house lizard) as shown in the extract below.

Maad ke rongit kanih, yoh man tubi'. Yoh suak man tubi', tibulit mo' mun kaang tanak. Oni kowo' de man pak eh nyam paguh nagn to' man danih, doik nak de nyam to' man tanak datik...Jadin tibulit moh maat tiak ke rongit tiak, yoh mok mitiak odop eh mit eh...jadi yeh moh ye mit eh.

(Go up the skies, it ate rice. House lizards went down to the land/earth. What is it that the people eat up there, so good it seemed. 
Not like what we eat here on the ground...so, house lizard climbed to the skies, and it took it (the rice.)

(D8, L3-5; L14-16)

The two extracts above illustrate the status of rice in the Bidayuh community. Rice is an important staple, and it is highly revered as it originated from the heavens. This may indicate the Bidayuh worldview that the food they eat is precious and they have to respect all the rituals that go along with paddy planting. For this reason, various types of Gawai relate to paddy planting. As mentioned previously in Table 1, six different types of Gawai are conducted at the different stages of podi planting.

In another dondan, Dondan Sikau Bungak, an important IK related to the planting process of podi was found.

'...mak diyok man, samak mu gituang eh nuok', in sinok eh. Aluakaluak samak eh nuok...Samak eh mokuok nuok, tiyak man. 'Kajon samak mu obuok nobong', in eh...kajon samak eh obuok nobong. Mokuok nobong, mitak odop eh nyak man. Siniak reh odak eh bisowaksowak neh, nog ngokas, nog nuruk, nog nyobu, nog ngutuam.

('Do not eat yet, your father just started clearing the field,' the mother said. The father has not finished clearing...After the father finished clearing, he asked for food. 'Wait until your father has finished cutting the trees,' she said. .. (he) waited until the father finished cutting the trees. After cutting the trees, he asked for food. That is how it is for years, after planting, after weeding, after clearing, after harvesting.)

(D4, L5-12)

The planting of podi consists of several steps, starting with ngawah which is a trip made by the farmer to the selected area to ensure that the land is suitable for planting podi as well as to observe good and bad omen. This was then followed by nau, which is the clearing of the forest, by cutting down the small trees, undergrowth and grass in the area. Nobong, which is the felling of the trees, then follows. Ngokas comes after nobong. It is the cleaning up of burnt debris after the burning of the field. After all that, the planting process, known as nuruk is carried out. The podi grains are placed inside a hole in the ground, which was made using wooden poles. Before the harvesting season, $n y o b u$, or weeding is done and lastly, the ripened podi are harvested or 
ngutuom. Each step is equally important as another and needs to be conducted carefully to ensure that the harvest is abundant.

The dondan not only depicts the discipline and methodically organised characteristics of the Bidayuh, but it also describes the life activities of the Bidayuh according to the time of year. In the olden days, there was no calendar, which one could refer to. Therefore, the planting cycle was used as a guide to tell the time of the year. Each step of the planting process was done in accordance with the general weather condition. For example, November to February was usually the rainy season. Thus, nyobu or weeding was usually carried out around that time of the year. Ngawah, nau and nobong were usually the activities carried out between June to August because during that period the weather was hot and there was minimal rain. Subsequently, they waited for the land to dry before carrying out the burning of the field, which would usually be before October. Nuruk, which is the planting of the seeds, would usually take place around October. Subsequently, when the rainy season comes along, between November and February, there would be plenty of water for the podi. It was between April and May that the ngutuom, or harvesting, was done, as at that time, the podi would have ripened.

Apart from using podi planting as a clue to the time of year, another IK, which can be extracted from this, is the use of the weather to help with the mass planting of podi. The Bidayuh uses the time of year and weather conditions to their advantage. Podi planting is usually done on a big area of land; therefore, they would need the help of Ieng Podi or the spirit of the podi to ensure that the harvest would be aplenty.

The Bidayuh also use to their advantage, their knowledge of the habits of wild animals to help deter them from disturbing the podi plants. Different types of vegetation are planted alongside the crop to divert the animals from eating the podi. Rather than consuming the podi, they would instead consume the other vegetation. To illustrate:

Yoh mok nak jagung, alum, sabih, srangai, jagum, banuok, tobuh, stila, kuduk nak eh da'ang juwah eh neh. 'Nai oni koyuh tih?' in eh nang Sikora. 'Ehhh,' in eh nang Ayang, 'Itih neh jading gogar jading ijuon eh. Binatang de yak man pinimul pingajih, yoh mo ogik koyuh de mutik de yak man eh, yoh mo dik man eh, 'in eh.

(So she puts corn, wild spinach, corn, tapioca, sugarcane, and yam in the basket. 'Why do you put these in?' asked Ayang. "These things are useful to help protect your podi from animals. 
With these things they will not eat your podi because they have these to eat.')

(D14, L 61-65)

The above extract illustrates the ingenuity of the Bidayuh who find a different way to handle pests that might destroy their crops. In knowing the kind of food that the animals eat, they are able to divert them from devouring the podi.

Another feature of the Bidayuh is their respect for nature including animals. In their worldview, animals, spirits, and humans may interchangeably take on different forms. For example, in some of their folk narratives, the wild boar turns out to be a human relative who in turn may at another instance be a 'star'. They avoid killing animals unless it is for the purpose of consumption as animals are a source of food. However, they are not killed indiscriminately. This could also be seen as a form of respect for the animals.

It is undisputable that podi is an extremely significant part of the Bidayuh community. This is further supported by the fact that at every stage of the podi planting and harvesting process, a specific Gawai ritual is performed. This is to ensure that the Paddy Spirit, Ieng Podi gives its blessing. The extract below illustrates:

Sikora mo' ngajar eh pakai gawia. Nang lagu gawia in neh. Ngan ku ngajar mu' dak mu' bigawia in neh. Sak mu bitandak bigawia podi in neh. Bigawia pinimul pingajih in eh. Yoh mok nai eh. Nai gawia..oni wat nyek nai eh in neh. Sibungas eh, diok in eh nyarik sukuai, nyarik pogang, nak sukak eh in eh nak de u'un tonyuk in neh. Mokuo noh nyek mok nyarik baris odak pat sarik in neh. Nyek mok mitia poi pat nyek mo' nai sikapul in neh, pabila sadih pat, pat bidiap pat ngisarik..bai basa de juk, juk geh, sarik bai eh juk geh. Ba moih, moih geh in neh. Yoh wat noh wat eh ngajar Ayang neh. Jadin yoh mok mokuo ngajar eh, yoh mok nang motak nai tonyuk. Inoh de nang Sikora neh. Kan ya' ngutuom in eh nang sonik noh Ayang. Ayang motak ke tonyuk nai dak paguh. Yoh mo' motak ke salah tonyuk mun tih neh.

(Sikora teaches him how to do the Gawai.To sing the Gawai song he said. Here I teach you the song of the Gawai he said. So that you know how to conduct the Gawai. To do the Gawai of pinimul pingajih he said. So he did it. Did the Gawai. Here is how they do it. First, prepare the sukuai, pogang, put vineger. Put it on the tonyuk he said. After that, prepare the other offerings. He asked for four poi to do the four 
sikapul he said, when there are four sadis, there should be four types. Seven sadis, seven areca nut, when there is eight, everything should be eight. That is how Sikora teaches Ayang. After teaching him, it teaches him how to build a tonyuk. That is what Sikora told. When people go harvesting it told Ayang. Ayang went up the tonyuk to make it better. This is how he built tonyuk.)

(D14, L28-37)

In the extract, sikora, which means 'a star' teaches Ayang, a Bidayuh person, how to conduct the Gawai. According to Bidayuh myth, a sikora named Saya taught the Bidayuh people how to conduct the different Gawai related to podi. This was done to appease the Ieng Podi so that they may have a bountiful harvest every year.

\section{Cultural Categories of podi}

A number of lexical items which are related to podi are also mentioned in the dondan such as the different tools and equipment used.

Based on Figure 1 above, categories related to podi can be divided into four - the process, equipment, produce, and parts of podi. As mentioned in the previous section, there are a number of steps involved in the planting process; they are nau, nobong, ngokas, nuruk, nyobu and ngutuom. Besides that, equipment used for podi planting are also found in the dondan such as bukuo' which is a type of machete used to clear the forest and for weeding. In addition, different types of baskets are used to carry podi such as tajau, juwah and jumuok, which are different in sizes. Then, there is also the mention of the places where podi is stored such as pitak and kayan. The difference between these two is that the pitak is rectangular while the kayan is round. Kayan is also larger than pitak. Both are made out of tree bark. Risuong is a mortar made from Belian tree or ironwood. It is used to pound the husked podi, which is boras to be made into flour.

In the produce category, two items are mentioned - tubi, which is, cooked rice and a staple food of the Bidayuh and pogang, which is glutinous, rice cooked in bamboo. Pogang is also a traditional food consumed by the people during special occasions and also served as part of the offerings to the paddy spirit, Ieng Podi and spirits of the ancestors, Ieng Sumuk Babai.

Two parts of podi are found in the dondan and they are buwa' podi or the seed of paddy and tongon podi which is the stalk of the paddy. 
Figure 1: Cultural Categories related to podi

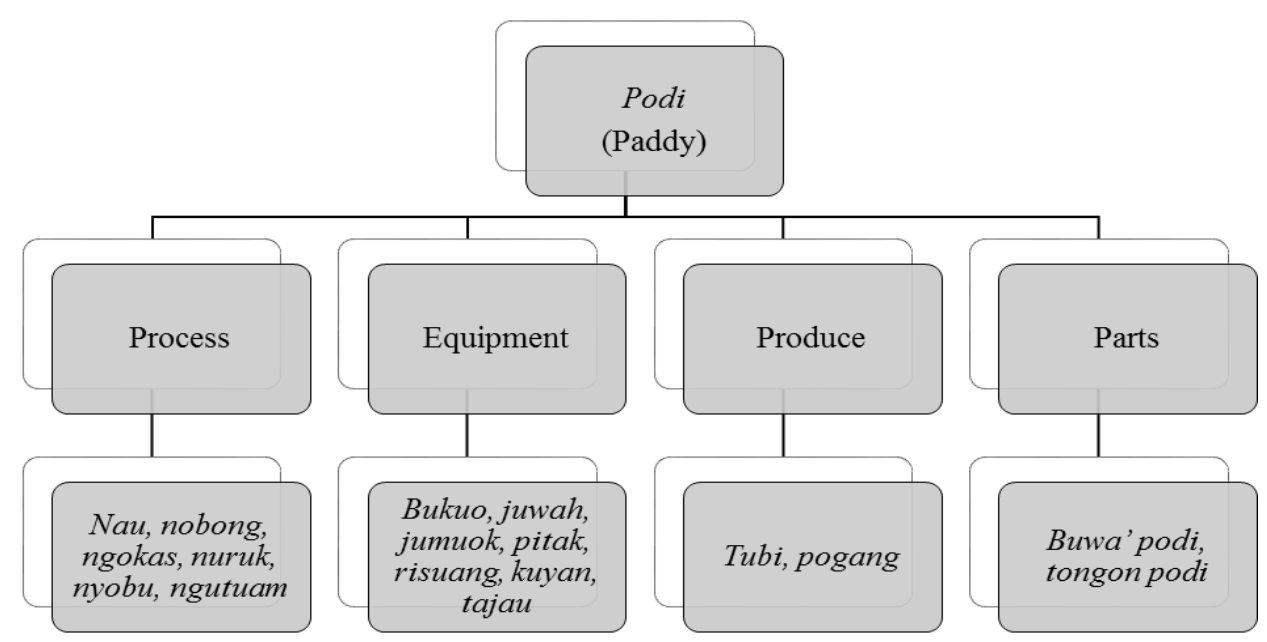

All these important items on paddy planting are relayed in the dondan, which makes it an important platform to teach younger generations on how to plant paddy in the right way. The IK is embedded in the dondan, which serves as an educational tool.

\section{Cultural Metaphors related to podi}

As discussed above, podi is a significant cultural element within the Bidayuh community. This significance is further enhanced by the metaphors used to expound the value of the podi. Dondan Tibulit illustrates the significance of podi and is expressed through cultural metaphors:

Yoh ngan eh adon pinimul pingajih neh in eh. Nai nikan noh adon sikadod sikonyang in neh. Nikan noh tah to' tonok to' mo'man, otin to madod, tulang to mo' poras odak eh in neh. Noh neh sikadod sikonyang in neh. Yoh mok tibult bikadod in nang pinimul pingajih sikadod sikonyang in neh.

(That is what we call 'pinimul pingajih,' he said. Do that one is called 'sikadod sikonyang,' he said. That one we cook we eat, our heart cool, our bones become hot because of it, he said. That is what we call 'sikodad sikonyang,' he said. That is why house lizard said it is 'pinimul pingaji sikadod sikonyang,' he said.) (D8, L9-12) 
Podi is known as pinimul pengajih sikadod sikonyang which literally means 'to bring good luck and prosperity to all efforts and wishing that all will result in good outcomes and bring successes'. The metaphor used illustrates the power of the podi that has the ability to bring good luck, prosperity, good outcomes, and success. Notwithstanding, within the worldview of the Bidayuh one also needs to put in the effort in order to achieve positive results.

In the following extract, the metaphor used demonstrates the ability of the podi to multiply:

Inoh de nang koih pinimul pingajih sikadod sikonyang in neh. Nang nai eh adon sikadod sikonyang neh pinimuk pingajih in neh. Nik kruang puluah ponai nog nik ayon. Yoh mok eh ratus kluang eh in neh.

(That is what we call pinimul pingajih sikadod sikonyang. One grain makes up tens of grains and hundreds of grains.)

(D8, L7-9)

The metaphor Nik kruang puluah ponai nog nik ayon. Yoh mok eh ratus kluang eh can be interpreted as 'a single grain will multiply to produce a large number of podi grains' is another metaphor which reflects the Bidayuh worldview of how great and significant the podi is. Such is the status of the podi that the Bidayuh community respects.

\section{Cultural Schemas related to Headhunting}

As indicated earlier, the focus of this paper is the cultural schemas of podi planting and headhunting, or odi ngoyu, found in the dondan. Both are discussed in the context of Gawai, a form of traditional celebration according to the Bidayuh custom.

Odi ngoyu is reflected in Dondan Sibunyuah. In the dondan, cultural schemas related to the steps or procedures for hunting are relayed. For example, the steps discussed are to do with making preparations before going on the hunt, the appropriate age for hunting, the perfect time to go hunting, what one should do when hunting, who should go and for what purpose, and what should be done after hunting.

Before embarking on a headhunting expedition, there are certain preparations that need to be undertaken. Besides that, a person has to reach a certain age before he is considered 'ready' to go on a headhunting expedition. To illustrate: 
Pabila madih eh noh ningak pinanak eh noh mok ayuh ngijak duwoh ponu. 'Onak soma $k u$ ' in eh. Yoh mok nai asur eh, nai ubat eh, nai eh daik eh, pinyata tudu eh. 'Pakai otok odi ngoyu,' in eh motak dek toyak samak mu'u.' in eh. Yoh moh ponu tiyak neh, soma eh diyok ponu oran... Odi ngoyu jak.

When the brother saw his nephew old enough, he asked him to go hunt together. 'My brother's son,' he said. He prepared the arrows, the poison, the darts, everything for it. 'For us to go headhunting' he said while going to his father's farm. They walked together, his uncle first...go headhunting.

(D12, L4-6)

Eh mok idoh dik ponu nik minggu, duwoh minggu. Ngijak eh duwoh motak, odak eh nai eh geh. 'Ba onu moh paguh, tiek odi motak, ngoyu,' in eh. Nog mok soma eh noh diyok-diyok nai otag, nai asur, nai juwah, nai jumuak, eh neh.

He did not walk for one week, two weeks. Ask him to come along, ask him to do it. 'The day is good, come lets go headhunting,' he said. The uncle came and prepared the poison, arrow, baskets.

(D12, L10-11)

Pabila yoh gitung mokat bujang, soma eh mok toban odi motak. Odi motak, odi ngoyu. 'Jak otok odi ngoyu tiyak,' in eh. Soma eh moh ponu. Nog kubur no 3 tiyak, kan eh nog, soma eh mok kirin eh, onu aluak sak jawak, kan eh nog, soma eh kip sakap eh, bila mun madih dek munok bikoduh bu'u.

When he has reached puberty, his uncle brings him to the farm. Go walking, go headhunting. 'Let us go headhunting,' he said. His uncle walked. Until they reached the third grave, his uncle saw him; it was not yet morning, they reached the place, but his brothers ran away.

(D12, L13-15)

In all the extracts above (D12, L4-6; D12, L10-11; D12, L13-15) the Cultural Schema illustrates that the appropriate time to bring a boy for headhunting, or ngoyu, is when the boy has come of age, in other words, reached puberty or mokat bujang. This would most probably be about 13 or 14 years old. 
The dondan also contains IK that is related to the preparation of weapons for $n g o y u$. For example, the dondan educates on how to prepare the arrow and its poison (Yoh mok nai asur eh, nai ubat eh, nai eh daik eh, pinyata tudu eh); and, when to go headhunting, i.e. only certain times are considered as having good omen, and those are the only times headhunting expeditions can take place (Nog mok soma eh noh diyok-diyok nai otag, nai asur, nai juwah, nai jumuak). Ngoyu usually takes place in the early mornings (Ba onu moh paguh, tiek odi motak, ngoyu, onu aluak sak jawak) when the sun has not risen yet.

Ingan duwoh madih ro'o, oku odi ngibun Kutang-Katung', in eh. Ma'at ngibun Kutang-Katung eh tiyak neh.... Yoh mok tanon odop eh ponu merantau jog eh in odop eh

'You two brothers stay, I will go and look out for Kutang-Katung,' he said. He went and looked out for Kutang-Katung...He went and said that he wanted to go out hunting.

(D12, L 19-20)

\section{Cultural Models}

\section{Podi}

For the Bidayuh of Sarawak, podi is their staple food. Podi is an important cultural entity in the Bidayuh community. In fact, podi is regarded as a symbol of health and wealth among the Bidayuh. In the Bidayuh language, there are three terms that refer to rice - Podi is the unhusked rice, or paddy, which is cultivated either on the hills or swamps, boras are husked rice and tubi' are cooked rice.

Podi as a symbol of health is the staple food for the Bidayuh. According to Patrick (2002), 'A Bidayuh did not consider that he had eaten if he had consumed a plate of noodles, for example. That was a mere snack' (12). This indicates that consuming rice is necessary for the Bidayuh. Patrick (2002) also contends that 'Rice, therefore, had to be eaten for a meal to be satisfying' (12). The Cultural Schemas on podi reveals that the Bidayuh believes that podi is the food from the skies or rongit, and that consuming it would bring not only good health and energy but good luck and prosperity as well.

The fact that a single podi grain could produce more podi by multiplying into millions of grains gives it the notion of wealth. In fact, podi is kept in a special place known as pitak and kayan. For the Bidayuh, a family, 
which has a large supply of paddy, was regarded as wealthy (Nuek, 2002), thus paddy is a symbol of wealth.

This being the case, the Bidayuh respects the podi seeds and handle them with great care. Each grain of podi is precious. If it were to fall to the ground, it must be picked up even to the last grain.

There are about five steps in podi planting, and each is carried out carefully. Before they do it, however, a Gawai needs to be carried out. This is to ensure that blessing is obtained from the spirits and that a good harvest would be produced every year. In fact, Gawai itself was taught by Sikora to the Bidayuh people so that the harvest would be abundant.

Another IK that could be extracted is the use of the weather to help with the mass planting of podi. As discussed earlier, the Bidayuh used the time of the year and weather conditions to their advantage. Podi planting is usually done on a big area of land. Therefore, they would need the help of the Mother Nature, or in this case, the paddy spirit, Ieng Podi to ensure that the harvest would be aplenty.

\section{Cultural Model of Ngoyu}

Headhunting is known as ngoyu in Bidayuh. Therefore odi ngoyu means 'to go headhunting'. Headhunting for the Bidayuh is not about seeking enemies to behead them. Most of the time headhunting is only done to avenge the death of a person or an attack on a Bidayuh village. Therefore, to the Bidayuh, headhunting is a form of retaliation.

Headhunting is also an important cultural element which is related to Gawai. It was usually carried out only when necessary. In most instances, it was carried out when there was a need to protect their village.

\section{Conclusion}

IK is embedded in both tangible and intangible cultural heritage. In this study, the focus was on a type of intangible cultural heritage that is the folk narratives or dondan, as the Bidayuh Bau-Jagoi calls them. This study shows that folk narratives can be a source of IK because it contains information concerning the Bidayuh people especially on their beliefs and how they conduct important activities.

This study looks into two main areas of the Bidayuh Bau-Jagoi life, namely farming and hunting. In the olden days, the Bidayuh were farmers and rice was their staple food. In the dondan, several of them were set in a 
farming setting and two consist of the history and rituals concerning podi planting.

Hunting was also a source of food for the Bidayuh. Living mainly in the hilly areas of the mountains, the Bidayuh were surrounded by thick virgin forests, which supplied them with wild animals suitable for consumption. Hunting was a method used to get these animals on the dinner table. Again, this dondan were set against a forestry background and the stories were related to hunting. While the dondan under study are focused on podi cultivation and headhunting, the IK within can be applied to the process and rituals on hunting animals for food. Indirectly the dondan do contain IK, which are important to the Bidayuh that could be used as a guide for the younger generations in terms of farming and hunting.

\section{References}

Chang, P. F. (2002). History of Bidayuh in Kuching Division, Sarawak. Kuching: Sarawak Press

Chang, P. F. (2004). History of Bidayuh in Kota Samarahan Division, Sarawak. Kuching: Sarawak Press

Chielotam, N. A., (2012). Expressing indigenous knowledge through dance. African Journal of History and Culture, 4(5), 69-73.

Flavier, J., de Jesus, A. \& Navarro, C. (1995). The regional program for the promotion of Indigenous knowledge in Asia. In D. Warren, L Slikkerveer and D. Brokensha (eds.), The Cultural Dimension of Development: Indigenous knowledge systems (pp. 479-487). London: Intermediate Technology Publications.

Harrison, D. K. (2007). When Languages Die: The Extinction of the World's Languages and the Erosion of Human Knowledge. London: Oxford University Press

Hussin, H. (2007). Worldview dan amalan: Pengalaman Kadazan dataran Penampang Sabah. Borneo Research Journal, 2, 7-29.

Hussin, H. (2008). Diaspora Bajau Laut dan pengekalan serta penerusan amalan tradisi di Sabah. Borneo Research Journal, 2, 149-163.

Lakoff, G. \& Johnson, M. (1980). Metaphors we live by. Chicago: University of Chicago Press.

Nuek, P. R. (2002). A Dayak Bidayuh community: rituals, ceremonies E festivals. Kuching: Sarawak Press. 
Pugh-Kitingan, J., Hussin, H. \& Baptist, J. J. (2009). Symbolic articulation of interactions between the seen and the unseen through gong music and dance in the lotud Mamahui Pogun. Borneo Research Journal, 3, 221-237).

Ridu, R. S., Jitab, R., \& Noeb, J. (2001). King Siliman and other Bidayuh folktales. Kota Samarahan: Universiti Malaysia Sarawak.

Sharifian, F. (2011). Cultural conceptualizations in intercultural communication: a study of Aboriginal and non-Aboriginal Australians. Journal of Pragmatics, 42, 3367-3376.

Tamit, S. D. D. W. (2009). Kampong Ayer Brunei Darussalam: meniti arus pembangunan. Borneo Research Journal, 3, 209-219.

Warren, D. M. (1991). Using indigenous knowledge in agricultural development (No. 127). World Bank. 